\title{
Effect of Indomethacin on Cerebral Oxidized Cytochrome Oxidase in Preterm Infants
}

\author{
D. C. McCORMiCK, A. D. EDWARdS, G. C. BROWN, J. S. WYATT, A. POTTER, M. COPE, \\ D. T. DELPY, AND E. O. R. REYNOLDS \\ Departments of Paediatrics, Biochemistry, and Medical Physics and Bioengineering, University College and \\ Middlesex School of Medicine, London, WCIE 6JJ, England
}

\begin{abstract}
To determine the effect of i.v. indomethacin on cerebral intracellular oxygenation, as judged by changes in the concentration of oxidized cytochrome oxidase, studies were performed using near-infrared spectroscopy on 15 infants of 23 to 29 wk gestation, aged 8 to $30 \mathrm{~d}$, who required the drug for closure of a patent ductus arteriosus. Indomethacin caused significant $(p<0.01)$ falls in cerebral blood flow, oxygen delivery, and blood volume and its reactivity to changes in arterial carbon dioxide tension, as previously reported. In 11 of the 15 infants, significant ( $p$ $<0.01$ ) falls of 0.18 to $0.92 \mu \mathrm{mol} \cdot \mathrm{L}^{-1}$ in the concentration of oxidized cytochrome oxidase were observed. Parallel experiments on synaptosomes derived from rat brain showed that indomethacin was most unlikely to have had a direct effect on mitochondrial respiration. These results are consistent with the hypothesis that the observed falls in the concentration of oxidized cytochrome oxidase resulted from hemodynamic perturbations that reduced cerebral intracellular oxygenation. (Pediatr Res 33: 603-608, 1993)
\end{abstract}

Abbreviations

CBF, cerebral blood flow

$\mathrm{CBV}$, cerebral blood volume

$\mathrm{CBVR}$, response of $\mathrm{CBV}$ to changes in $\mathrm{PaCO}_{2}$

COD, cerebral oxygen delivery

MABP, mean arterial blood pressure

NIRS, near infrared spectroscopy

$\mathrm{PaCO}_{2}$, arterial carbon dioxide tension

$\mathrm{PaO}_{2}$, arterial oxygen tension

PDA, patent ductus arteriosus

$\mathrm{pH}_{\mathrm{a}}$, arterial $\mathrm{pH}$

[CytO $\mathrm{C}_{2}$, cerebral oxidized cytochrome oxidase concentration

$\left[\mathrm{HbO}_{2}\right]$, cerebral oxyhemoglobin concentration

[Hb], cerebral deoxyhemoglobin concentration

Administration of indomethacin to preterm infants disrupts cerebral hemodynamics, causing significant falls in $\mathrm{CBF}, \mathrm{CBV}$ and CBVR $(1,2)$. In some infants, COD falls below the level at which brain function would be impaired in adults, and although cerebral metabolic rate for oxygen is lower in preterm infants (3), it is possible that oxygen delivery to some regions of the brain may be critically impaired. As indomethacin is commonly used for the treatment of PDA in preterm infants and has

Received January 24, 1992; accepted November 3, 1992.

Correspondence: Prof. A. D. Edwards, Department of Paediatrics and Neonatal Medicine, Royal Postgraduate Medical School, Du Cane Rd., London W12 ONN.

Supported by the Medical Research Council, the Wellcome Trust, the Wolfson Foundation, and Hamamatsu Photonics KK. also been suggested as having a role in the prevention of periventricular hemorrhage, this potentially adverse effect is of concern $(4,5)$.

The purpose of this study was to investigate in preterm infants the effects of i.v. indomethacin on cerebral intracellular oxygenation as judged by changes in the concentration of $\left[\mathrm{CytO}_{2}\right]$, using NIRS to quantify alterations in $\left[\mathrm{CytO}_{2}\right]$ and cerebral hemodynamics. Cytochrome oxidase is the terminal enzyme of the mitochondrial electron transport chain. There is evidence that, as intramitochondrial $\mathrm{PO}_{2}$ falls to low levels, the enzyme becomes progressively reduced $(6,7)$. Thus, if indomethacin significantly reduced intramitochondrial oxygen tension, $\left[\mathrm{CytO}_{2}\right]$ should fall. Because of the possibility that indomethacin might have additional effects, causing changes in $\left[\mathrm{CytO}_{2}\right]$ that were not related to intramitochondrial oxygen tension, we have also investigated the effect of indomethacin on the respiratory rate of isolated synaptic terminals of brain neurons (synaptosomes).

\section{MATERIALS AND METHODS}

Subjects. Fifteen newborn infants who had been admitted to the neonatal unit of University College Hospital and who were receiving indomethacin for treatment of PDA were studied. Seven were male, and eight were female. Their gestational ages ranged from 23 to 29 (median 26) wk and their birth weights from 600 to 1590 (median 860) g. The diagnosis of clinically significant PDA was made when the characteristic cardiac murmur was associated with bounding peripheral pulses and an enlarged liver, and in each infant the diagnosis was confirmed by echocardiography. Indomethacin was administered into a peripheral vein in a dose of either 0.1 or $0.2 \mathrm{mg} \cdot \mathrm{kg}^{-1}$; eight infants received indomethacin by fast infusion over $30 \mathrm{~s}$, and seven by slow infusion over 20 to $30 \mathrm{~min}$. All infants suffered from hyaline membrane disease or chronic lung disease and were studied during the first dose of indomethacin. Clinical details and cranial ultrasound findings for the infants studied are listed in Table 1. Data for CBF, COD, CBV, and CBVR in nine of these infants have been reported previously (1).

Consent for the investigation was obtained from each infant's parents before each study and the project was approved by the University College London Faculty of Clinical Sciences Committee on the Ethics of Clinical Investigation.

NIRS. This technique depends on the characteristic absorption by the chromophores $\mathrm{HbO}_{2}, \mathrm{Hb}$, and $\mathrm{CytO}_{2}$ of near-infrared light transmitted through the head. Changes in chromophore concentration can be calculated from changes in light absorption using a modification of the Beer-Lambert law, which describes optical absorption in a highly scattering medium:

$$
\text { Absorption }(\mathrm{OD})=\mathrm{acLB}+\mathrm{G}
$$

where $\mathrm{a}$ is the absorption coefficient of the chromophore $\left(\mathrm{mM}^{-1}\right.$ - $\mathrm{cm}^{-1}$ ), $\mathrm{c}$ is the concentration of the chromophore (mM), $\mathrm{L}$ is the distance between the points where light enters and leaves the 
Table 1. Clinical details and changes in $\left[\mathrm{Cyt}_{2}\right]^{*}$

\begin{tabular}{|c|c|c|c|c|c|c|c|c|c|c|c|}
\hline No. & BW (g) & $\begin{array}{l}\text { Gestation } \\
\text { (wk) }\end{array}$ & Age (d) & $\begin{array}{l}\mathrm{Hb}(\mathrm{g} . \\
\left.\mathrm{dL}^{-1}\right)\end{array}$ & $\mathrm{pH}_{\mathrm{a}}$ & $\begin{array}{l}\mathrm{PaO}_{2} \\
(\mathrm{kPa})\end{array}$ & $\begin{array}{c}\mathrm{PaCO}_{2} \\
(\mathrm{kPa})\end{array}$ & $\begin{array}{c}\text { MABP } \\
(\mathrm{mm} \mathrm{Hg})\end{array}$ & $\begin{array}{c}\text { Cerebral } \\
\text { ultrasound }\end{array}$ & Ventilation & $\begin{array}{c}\Delta\left[\mathrm{CytO}_{2}\right] \\
(\mu \mathrm{mol} . \\
\left.L^{-1}\right)\end{array}$ \\
\hline 1 & 880 & 28 & 12 & 10.6 & 7.29 & 7.5 & 7.9 & 40 & Normal & Spont & -0.16 \\
\hline 2 & 830 & 25 & 12 & 14.7 & 7.24 & 6.2 & 9.8 & 42 & Normal & Mask & $-0.18 \dagger$ \\
\hline 3 & 1590 & 28 & 14 & 10.7 & 7.18 & 12.3 & 12.4 & 33 & Normal & Mask & $-0.64 \dagger$ \\
\hline 4 & 850 & 26 & 12 & 11.7 & 7.31 & 8.5 & 7.6 & 35 & MVD.GLH & Mask & $-0.34 \dagger$ \\
\hline 5 & 950 & 29 & 11 & 12.8 & 7.28 & 5.9 & 7.6 & & Normal & Mask & $-0.14 \dagger$ \\
\hline 6 & 1070 & 28 & 9 & 11.3 & 7.38 & 7.2 & 5.4 & 35 & IVH & IPPV & $-0.33 \dagger$ \\
\hline 7 & 704 & 25 & 23 & 10.7 & 7.36 & 9.3 & 7.0 & 36 & IVH, cyst & IPPV & $-0.42 \dagger$ \\
\hline 8 & 860 & 26 & 30 & 11.9 & 7.40 & 8.4 & 7.5 & 38 & Cyst & IPPV & $-0.48 \dagger$ \\
\hline 9 & 850 & 29 & 27 & 10.8 & 7.24 & 10.9 & 7.8 & 40 & MVD & IPPV & $-0.44 \dagger$ \\
\hline 10 & 660 & 26 & 20 & 11.5 & 7.20 & 8.3 & 9.0 & 43 & Normal & IPPV & $-0.32 \dagger$ \\
\hline 11 & 600 & 23 & 15 & 12.1 & 7.16 & 10.4 & 8.8 & 34 & Normal & IPPV & $-0.92 \dagger$ \\
\hline 12 & 1330 & 28 & 8 & 12.5 & 7.28 & 8.3 & 4.8 & 41 & Normal & IPPV & $-0.24 \dagger$ \\
\hline 13 & 710 & 26 & 12 & 10.7 & 7.19 & 8.7 & 6.0 & 27 & HPI & IPPV & -0.02 \\
\hline 14 & 1020 & 28 & 22 & 13.1 & 7.34 & 6.0 & 8.6 & 37 & IVH & IPPV & 0.00 \\
\hline 15 & 860 & 26 & 25 & 13.3 & 7.40 & 8.0 & 7.0 & 54 & Normal & IPPV & -0.01 \\
\hline
\end{tabular}

* BW, body weight; MVD, moderate ventricular dilatation; GLH, germinal layer hemorrhage; IVH, intraventricular hemorrhage; HPI, hemorrhagic parenchymal infarction; cyst, parenchymal cyst(s); spont, spontaneously breathing; mask, intermittent positive pressure ventilation via mask; IPPV, intermittent positive pressure ventilation via endotracheal tube.

$\dagger p<0.01$.

tissue $(\mathrm{cm})$, B is a "pathlength factor" that takes account of the scattering of light in tissue (which causes the optical pathlength to be greater than $L$ ), and $G$ is a factor related to the tissue type and measurement geometry (8). If L, B, and G remain constant during a measurement, changes in chromophore concentration can be obtained from the expression:

$$
\Delta \mathrm{c}=\Delta \text { Absorption/aLB }
$$

The absorption coefficients of $\mathrm{CytO}_{2}, \mathrm{HbO}_{2}$, and $\mathrm{Hb}$ are known $(9,10)$, and a mean value for $\mathrm{B}$ of 4.39 has been obtained from the time of flight of photons through the neonatal brain (11).

Details of the NIRS system, which was developed at this institution, have been described elsewhere (9). For this study, a commercial prototype spectrophotometer (NIR 1000, Hamamatsu Photonics KK, Hamamatsu City, Japan) was used. Nearinfrared light at six wavelengths $(779,803,831,849,867$, and $908 \mathrm{~nm}$ ) was conveyed to the infant's head via a flexible fiber optic bundle. The end of the fiber (the "optode") was applied to the parietal area, and transmitted light emerging from the opposite parietal region was collected by another optode and fiber optic bundle leading to the photomultiplier detector in the NIR 1000. The distance between the optodes was measured using mechanical calipers. Changes in $\left[\mathrm{CytO}_{2}\right],\left[\mathrm{HbO}_{2}\right]$, and $[\mathrm{Hb}]$ were calculated from the changes in optical absorption using the linear least squares curve-fitting technique with the absorption coefficients and algorithms described previously $(10,12)$. To assess the stability of the technique, measurements were made every 20 $s$ on an infant who was undergoing intensive care but was undisturbed during the 60 -min measurement period. The SD of repeated measurements of $\left[\mathrm{CytO}_{2}\right]$ during this defined steady state was $0.01 \mu \mathrm{mol} \cdot \mathrm{L}^{-1}$, with no significant increase or decrease. The average SD for measurements of $\Delta\left[\mathrm{CytO}_{2}\right]$ in the study group during the 5 -min period before the administration of indomethacin was $0.15 \mu \mathrm{mol} \cdot \mathrm{mL}^{-1}$.

Procedure. The infants were studied continuously for 31 to 203 (median 100) min before indomethacin administration commenced and for 49 to 238 (median 89) min after it was completed. During this period, $\mathrm{PaO}_{2}$ and $\mathrm{PaCO}_{2}$ were estimated continuously using a Novametrix 850 (Novametrix, Wallingford, CT) transcutaneous electrode calibrated from analysis of arterial blood. Arterial oxygen saturation $\left(\mathrm{SaO}_{2}\right)$ was measured on every pulse beat using either a modified Novametrix 500 (Novametrix) or Nellcor (Nellcor Type BF, Nellcor Inc, Haywood, CA) pulse oximeter whose probe was sited on the ear or the lip. MABP was measured before and after indomethacin administration by an oscillometric method (Dinamap 1846SX, Critikon Corp, FL). Arterial $\mathrm{Hb}$ concentration was estimated by Coulter counter on a sample of blood drawn from the aorta (via a 3.5 or 5 French gauge catheter in the umbilical artery) or a peripheral artery. Cranial ultrasonography was performed using a $7.5-\mathrm{MHz}$ mechanical sector scanner (ATL 4, ATL Ltd., Letchworth, UK). Blood glucose concentration was not assessed in detail, but in all infants, values greater than $2 \mathrm{mmol} \cdot \mathrm{L}^{-1}$ were obtained at regular bedside testing (BMstix, Boehringer Mannheim, Mannheim, Germany) around the time of indomethacin administration.

Changes in $\left[\mathrm{CytO}_{2}\right],\left[\mathrm{HbO}_{2}\right]$, and $[\mathrm{Hb}]$ were recorded continuously and averaged over 20 -s periods for display at the cotside. The data were also stored on computer disc for later analysis. $\mathrm{CBF}, \mathrm{CBV}$, and CBVR were estimated both before and after indomethacin administration by the methods described previously (13-15). CBF measurement was possible in only 11 of the 15 infants studied and was measured one to six (median three) times 6 to $189 \mathrm{~min}$ before indomethacin and between one and eight (median three) times 5 to $110 \mathrm{~min}$ afterwards, with values from repeated measurements being averaged for further analysis. COD was calculated as the product of arterial oxygen concentration and CBF. CBV was measured continuously in all infants, and CBVR was measured in each infant once 5 to $120 \mathrm{~min}$ before and once 10 to $96 \mathrm{~min}$ after injection. A period of stability in clinical variables and the cotside display of the $\left[\mathrm{CytO}_{2}\right]$ signal lasting at least $5 \mathrm{~min}$ was required before the indomethacin was given, and changes in $\left[\mathrm{CytO}_{2}\right]$ were observed from the continuous data.

Data analysis. Baseline values for $\left[\mathrm{CytO}_{2}\right]$ were calculated as the mean of observations made every $20 \mathrm{~s}$ during the 5 -min periods immediately before the indomethacin infusion started and after it ended. The standard error of the difference between the two means was calculated for each infant using a standard formula for samples where the variances may differ considerably (16), and the significance of the difference was assessed according to Welch (17). Values of $p$ that were less than 0.01 were regarded as significant.

The averaged values for $\mathrm{CBF}, \mathrm{COD}, \mathrm{CBV}$, and CBVR before and after indomethacin for each infant were compared using paired $t$ test. The extent of change in these variables and in mean $\left[\mathrm{CytO}_{2}\right]$ were compared between the fast and slow infusion groups and between the groups receiving 0.1 or $0.2 \mathrm{mg} \cdot \mathrm{kg}^{-1}$ using unpaired $t$ test. Factors possibly related to the degree of change in $\left[\mathrm{CytO}_{2}\right]$ for each infant were examined by stepwise multiple linear regression analysis (SPSS-PC+, Chicago, IL) with 
values for birth weight, gestation, postnatal age, $\mathrm{MABP}, \mathrm{PaO}_{2}$, $\mathrm{PaCO}_{2}, \mathrm{pH}_{2}$, arterial $\mathrm{Hb}$ concentration, and the change in $\mathrm{CBF}$, $\mathrm{COD}, \mathrm{CBV}$, and CBVR analyzed as independent variables.

Synaptosome study. To investigate any direct effect of indomethacin on mitochondrial respiration, synaptosomes were isolated from the whole brains of 1-mo-old female Wistar rats by density-gradient centrifugation. Synaptosomes consist of presynaptic membrane surrounding cytosol, synaptic vesicles, and mitochondria, and provide a convenient in vitro model for studies of brain metabolism (18). Synaptosomal oxygen consumption reflects energy turnover, which depends on the rates of mitochondrial ATP production and consumption, providing a direct assay of the activity of cytochrome oxidase.

The effect of indomethacin on synaptosomal oxygen consumption was assayed either in the absence or presence of veratridine, which maximally stimulates respiration by opening sodium channels in the plasma membrane. Veratridine-treated preparations provide a model of maximally active neurons, whereas untreated preparations simulate inactive cells.

Synaptosomal protein was assayed by the Lowry method, with BSA as a standard, and synaptosomes were incubated at $0.6 \mathrm{mg}$ protein $\cdot \mathrm{mL}^{-1}$ in a Krebs phosphate-plus-glucose medium at $37^{\circ} \mathrm{C}(18)$. Mitochondrial respiration was measured continuously as oxygen consumption by a Clarke-type oxygen electrode (Rank, Bottisham, UK). Synaptosomes were preincubated in the oxygen electrode vessel for $10 \mathrm{~min}$, and then indomethacin (dissolved in DMSO) was added at a range of concentrations. Three separate synaptosome preparations were used and nine determinations of oxygen consumption were made between 1 and $5 \mathrm{~min}$ after the addition of indomethacin. Alternatively, the synaptosomes were preincubated for $5 \mathrm{~min}$; then $50 \mu \mathrm{M}$ veratridine were added, followed by indomethacin 5 min later. Here, six determinations of oxygen consumption in three separate preparations were made 1 to 5 min after indomethacin.

\section{RESULTS}

Cerebral effects of indomethacin in newborn infants. As previously reported (1), average $\mathrm{CBF}, \mathrm{CBV}$, and CBVR all fell significantly after indomethacin administration $(p<0.01)$. No significant difference in the extent of change of values for hemodynamic variables was found between the fast and slow infusion groups or between the groups receiving different doses of the drug; Table 2 therefore summarizes the hemodynamic data for the entire study group.

Figure 1 shows experimental results from two infants. One infant received indomethacin by fast and one by slow infusion, and each showed the largest fall in $\left[\mathrm{CytO}_{2}\right]$ in their infusion group. The values for change in mean $\left[\mathrm{CytO}_{2}\right]$ with the significance of the change for each infant are included in Table 1 and shown in Figure 2. Mean $\left[\mathrm{CytO}_{2}\right]$ fell significantly $(p<0.01)$ from the 5-min period immediately before the indomethacin infusion commenced to immediately after it finished in 11 of 15 infants. No significant difference was found between the fast and slow infusion groups in the extent of the change in $\left[\mathrm{CytO}_{2}\right]$. The time course of the fall in $\left[\mathrm{CytO}_{2}\right]$ closely followed that of the fall in $\mathrm{CBV}$, and there was a close correlation between these variables in the infants who showed a significant fall in $\left[\mathrm{CytO}_{2}\right]$. Some infants who demonstrated a significant fall showed a trend to- ward recovery in $\left[\mathrm{CytO}_{2}\right]$ after the indomethacin was given, but in most of these infants, $\left[\mathrm{CytO}_{2}\right]$ remained lower than the preindomethacin levels for the duration of the study. No significant relationship was found between the degree of change in $\left[\mathrm{CytO}_{2}\right]$ and birth weight, gestation, postnatal age, $\mathrm{MABP}, \mathrm{PaO}_{2}, \mathrm{PaCO}_{2}$, $\mathrm{pH}_{2}$, arterial $\mathrm{Hb}$ concentration, or the extent of the change in $\mathrm{CBF}, \mathrm{COD}, \mathrm{CBV}$, or CBVR.

Effects of indomethacin on synaptosomal respiration. Veratridine increased synaptosomal oxygen consumption to a mean of $204 \%$ (SD 13\%) of control values. In concentrations of less than $5 \mu \mathrm{g} \cdot \mathrm{mL}^{-1}$, indomethacin did not alter oxygen consumption either in the resting or the veratridine-stimulated preparations. Concentrations greater than $100 \mu \mathrm{g} \cdot \mathrm{mL}^{-1}$ were associated with a marked decline in oxygen consumption in veratridine-treated synaptosomes; half-inhibition of respiration occurred at approximately $150 \mu \mathrm{g} \cdot \mathrm{mL}^{-1}$ or $250 \mu \mathrm{g} \cdot \mathrm{mg}^{-1}$ protein. In untreated preparations, concentrations of indomethacin in excess of 100 $\mu \mathrm{g} \cdot \mathrm{mL}^{-1}$ initially stimulated and then inhibited oxygen consumption. These results are given in Figure 3. DMSO had no effect on synaptosomal oxygen consumption.

\section{DISCUSSION}

Accuracy of NIRS. The accuracy of NIRS for detecting changes of cerebral $\left[\mathrm{CytO}_{2}\right]$ in preterm infants has been discussed previously (19). Precise determination of changes in $\left[\mathrm{CytO}_{2}\right]$ requires accurate data for the absorption spectra of all mobile chromophores present and validity of the modified Beer-Lambert relationship. Near infrared spectra for $\mathrm{Hb}$ have now been measured under carefully controlled conditions by several groups $(6,10$, 20 ), and spectra for cytochrome oxidase obtained both from $\mathrm{Hb}$ free animals in vivo $(10,21,22)$ and from purified cytochrome extracts (23). Recent studies have shown that spectra measured in vivo and in vitro are identical (6) and confirmed that the brain normally contains only three mobile chromophores (24). The validity of the modified Beer-Lambert law in biologic tissue has been demonstrated both by theoretical modeling and experimental measurement (8) and is further supported by the close match between spectra measured in vivo and in vitro (6).

Measurements of changes in the attenuation of light at six wavelengths were analyzed using a linear least-squares technique. This allows calculation of changes in chromophore concentration together with the residual error. Analysis of residuals has shown them to be small, confirming that the data fit a three-chromophore model quite precisely (19). In a previous study using both linear and nonlinear analysis of spectra measured in rat brain, the latter method provided a more accurate fit, but the errors induced by linear calculation were small $(6,12)$. System noise and systematic error are a small fraction of the total signal (19).

Cerebral effects of indomethacin. Indomethacin is a potent inhibitor of cerebral prostanoid synthesis (25). Studies in newborn piglets suggest that vasodilator prostaglandins maintain CBF during hypotension (26) and high-pressure mechanical ventilation (27), although the increase in CBF that occurs during asphyxia is not prevented by indomethacin (28). Prostanoids are probably important in the coupling of CBF to brain energy metabolism, and indomethacin is thought to reduce $\mathrm{CBF}$ without directly affecting cerebral oxygen consumption (25). However, indomethacin causes different effects in some other species, and

Table 2. Hemodynamic data*

\begin{tabular}{|c|c|c|c|c|}
\hline & $\begin{array}{c}\mathrm{CBF}\left(\mathrm{mL} \cdot 100 \mathrm{~g}^{-1}\right. \\
\left.\mathrm{min}^{-1}\right) \dagger\end{array}$ & $\begin{array}{c}\operatorname{COD}\left(\mathrm{mL} \cdot 100 \mathrm{~g}^{-1}\right. \\
\left.\min ^{-1}\right) \dagger\end{array}$ & $\mathrm{CBV}\left(\mathrm{mL} \cdot 100 \mathrm{~g}^{-1}\right) \ddagger$ & CBVR $\left(\mathrm{mL} \cdot 100 \mathrm{~g}^{-1} \cdot \mathrm{kPa}^{-1}\right) \ddagger$ \\
\hline Before indomethacin & $33.11(10.51)$ & $3.51(0.99)$ & $3.53(0.86)$ & $0.15(0.06)$ \\
\hline After indomethacin & $19.71(9.31)$ & $2.08(0.89)$ & $2.73(0.78)$ & $0.03(0.05)$ \\
\hline
\end{tabular}

* Values are mean; numbers in parentheses are SD. The difference between mean values for all variables before and after indomethacin was significant $(p<0.01)$.

$\dagger n=11$.

$\ddagger n=15$. 


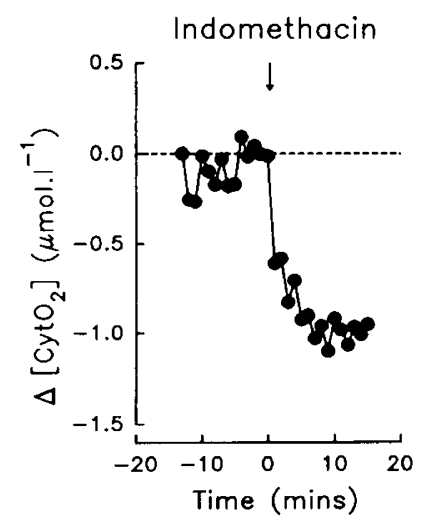

A

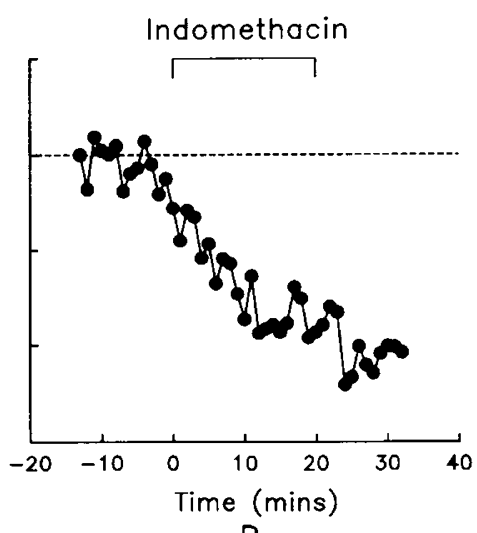

B
Fig. 1. Changes in $\left[\mathrm{CytO}_{2}\right]$ in two infants around the time of indomethacin administration. Each point represents a 1-min average from the continuous records. Graph $A$ is taken from the data for infant 3, who received indomethacin by fast infusion, and graph $B$ is taken from the data for infant II, who received the drug by slow infusion.

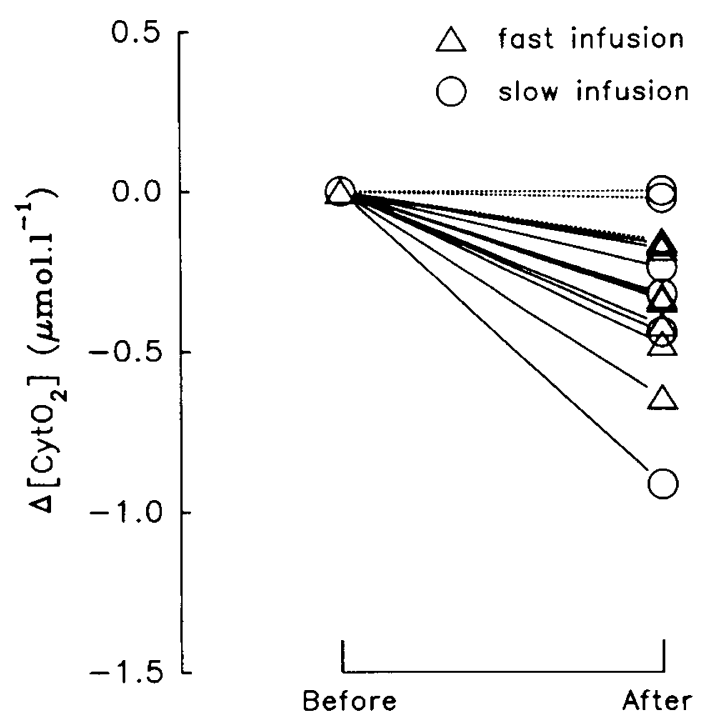

Fig. 2. Change in mean $\left[\mathrm{CytO}_{2}\right]$ from the 5-min period before to the 5 -min period after indomethacin for all infants. The preindomethacin mean $\left[\mathrm{CytO}_{2}\right]$ has been related to an arbitrary zero. Solid lines between symbols denote a significant $(p<0.01)$ change in $\left[\mathrm{CytO}_{2}\right]$.

extrapolation of such data to human infants requires circumspection (25). Indomethacin reduces $\mathrm{CBF}, \mathrm{COD}, \mathrm{CBV}$, and CBVR in newborn infants suffering from $\operatorname{PDA}(1,2)$, and the hemodynamic data presented previously (1) and in this report confirm that marked changes took place in the infants studied.

Cytochrome oxidase in the brain. Cytochrome oxidase is composed of 13 protein subunits, two heme units ( $A$ and $A_{3}$ ), and two copper atoms $\left(\mathrm{Cu}_{\mathrm{A}}\right.$ and $\left.\mathrm{Cu}_{\mathrm{B}}\right)(29)$. The $\mathrm{Cu}_{\mathrm{B}}$ and heme $\mathrm{A}_{3}$ form a binuclear unit that receives electrons from heme $A$ and $\mathrm{Cu}_{\mathrm{A}}$ moieties and is the final electron donor to dioxygen in the reaction that forms water (30); this reaction accounts for the great majority of oxygen consumption in biologic tissue (31). Electrons pass to $\mathrm{Cu}_{\mathrm{A}}$ from cytochrome $c$, and the oxidation levels of cytochrome $c$ and $\mathrm{Cu}_{\mathrm{A}}$ are similar under most conditions $(32,33)$. Absorption of near-infrared light by cytochrome oxidase occurs almost entirely at the $\mathrm{Cu}_{\mathrm{A}}$ center, the oxidized form of $\mathrm{Cu}_{\mathrm{A}}$ having a characteristic spectrum, whereas the reduced form has no distinguishable absorption (23). Near infrared measurements of changes in $\left[\mathrm{CytO}_{2}\right]$ thus measure alterations in the concentration of oxygenated $\mathrm{Cu}_{\mathrm{A}}$ and reflect the concentration of oxidized cytochrome $c$.

The concentration of oxidized $\mathrm{Cu}_{\mathrm{A}}$ depends on the supply of

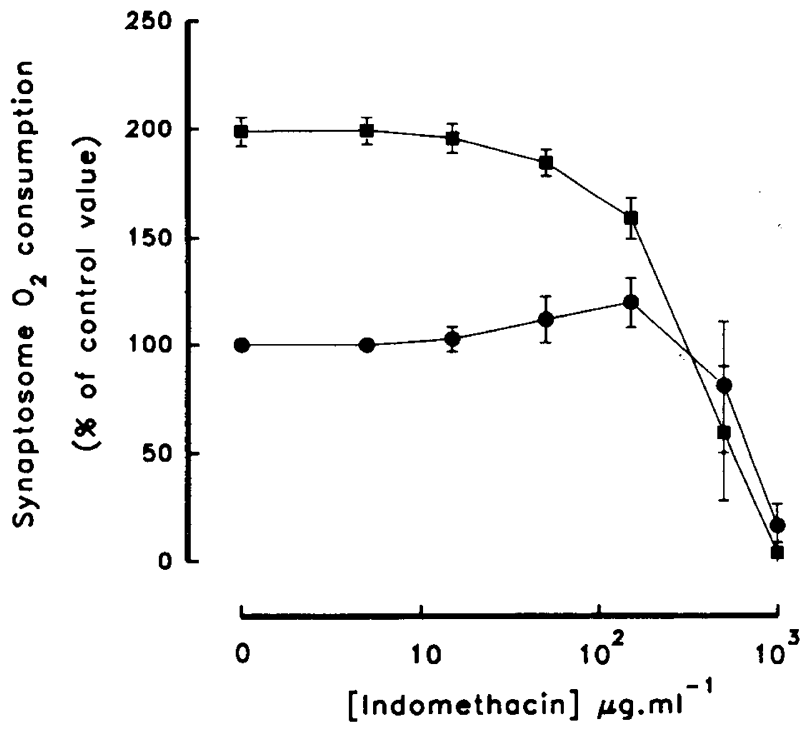

Fig. 3. Relation of synaptosomal oxygen consumption to indomethacin concentration in the absence $(n=4)$ and presence $(n=6)$ of veratridine. Mean \pm SD oxygen consumption is given as a percentage of the rate in the absence of either indomethacin or veratridine.

oxygen, the availability of respiratory electrons and the level of the mitochondrial proton-motive force, determined mainly by the rate of cellular ATP utilization $(32,33)$. Variations in oxygen delivery and consumption in brain produce heterogeneous tissue oxygen concentrations, distributed between 1 and $100 \mu \mathrm{M}$, with a median value of about $40 \mu \mathrm{M}(34,35)$. Measurements in isolated mitochondria have shown that the concentration of oxidized cytochrome $c$ begins to decrease at oxygen concentrations below $20 \mu \mathrm{M}$, although the respiration rate does not fall until the oxygen concentration is below 1 to $5 \mu \mathrm{M}(23)$; thus, a decrease in oxidized cytochrome $c$ is not necessarily equivalent to a fall in mitochondrial respiration rate. A decline in $\left[\mathrm{CytO}_{2}\right]$ may therefore demonstrate an increase in the fraction of brain where mitochondrial oxygen tension is below $20 \mu \mathrm{M}$. However, changes in $\left[\mathrm{CytO}_{2}\right]$ might also be precipitated by alterations in the rate of ATP utilization, changes in the supply of reducing equivalents, or the direct effect of drugs on mitochondrial function.

Changes in $\left[\mathrm{CytO}_{2}\right]$ after indomethacin. Significant falls in $\left[\mathrm{CytO}_{2}\right]$ were recorded in 11 of the 15 infants studied. No differences were detected between the effects of rapid and slow infusions of indomethacin or between different doses, but, inasmuch as the study did not address these questions directly, firm conclusions on dosage effects would be unwarranted.

The concentration of cytochrome oxidase in rat brain is approximately $5 \mu \mathrm{M}(36)$. The concentration in the newborn infant's brain has not been measured, but if it is similar, then the decreases in $\left[\mathrm{CytO}_{2}\right]$ observed in this study constitute between approximately 3 and $20 \%$ of the total concentration.

The 5-min periods chosen before beginning and after ending indomethacin infusions appeared to encompass most of the observed alterations in $\left[\mathrm{CytO}_{2}\right]$. However, it can be seen in Figure $1 A$ that a mean calculated over the 5 -min period immediately after fast infusion of indomethacin may underestimate the maximum change in $\left[\mathrm{CytO}_{2}\right]$. For some infants receiving indomethacin by slow infusion, the maximum changes were also sometimes underestimated, because some infants showed an initial fall in $\left[\mathrm{CytO}_{2}\right]$ followed by recovery before the infusion had finished.

Mechanism of effect of indomethacin on $\left[\mathrm{CytO}_{2}\right]$. Indomethacin is unlikely to have affected mitochondria directly. Mitochondrial respiration rate in synaptosomes did not change at concentrations of up to $5 \mu \mathrm{g} \cdot \mathrm{mL}^{-1}$, and, in preterm infants, serum levels after therapeutic indomethacin administration are less than 2 
$\mu \mathrm{g} \cdot \mathrm{mL}^{-1}$ (37). Because indomethacin binds strongly to proteins, it may be more relevant to compare doses per $\mathrm{mg}$ of protein. Doses of up to $10 \mu \mathrm{g} \cdot \mathrm{mg}^{-1}$ protein caused no change in synaptosomal respiration. Infusion of $0.2 \mathrm{mg} \cdot \mathrm{kg}^{-1}$ of indomethacin is equivalent to $2 \mathrm{ng}$ indomethacin $\cdot \mathrm{mg}^{-1}$ body protein (38). Although the synaptosomes were derived from adult rat brain, any mechanism by which indomethacin could affect energy metabolism directly is unlikely to differ dramatically between the two systems. The decline in $\left[\mathrm{CytO}_{2}\right]$ seen in the study group is thus probably better explained by changes in intracellular oxygenation caused by the hemodynamic effects of indomethacin than direct effects on cerebral energy metabolism.

However, a simple relation between $\mathrm{COD}$ and $\left[\mathrm{CytO}_{2}\right]$ has not emerged from this study; indeed, given the complexity of cerebral metabolic control, such a relation should not be expected. Both the mitochondrial respiration rate and the oxidation-reduction state of respiratory chain components change their dependence on oxygen concentration dramatically under different metabolic conditions (39). The variables studied would not have revealed metabolic heterogeneities that could modulate alterations in $\left[\mathrm{CytO}_{2}\right]$. The supply of respiratory electrons to mitochondria was not measured, and this may have been affected by differences in glucose metabolism. Cerebral glucose delivery, and ultimately the supply of reducing equivalents, would have declined with COD as CBF fell. Equally, cerebral ATP utilization was not assessed and may have been heterogeneous. $\left[\mathrm{CytO}_{2}\right]$ is thus a complex function of many variables and will not depend only on COD.

In addition, regional perfusion may have been altered. Energy metabolism in brain closely parallels CBF (31) and capillary density (40). Disruption of this precise relation might reduce substrate delivery to metabolically active regions even if total $\mathrm{CBF}$ did not alter significantly, with a consequent fall in $\left[\mathrm{CytO}_{2}\right]$. In a previous study, we offered evidence to suggest that microvascular alterations had a marked effect on $\left[\mathrm{CytO}_{2}\right](19)$. Again, the preexisting distribution of intracellular oxygen tensions would have significant effects on resulting alterations in $\left[\mathrm{CytO}_{2}\right] . \mathrm{It}$ is also possible that effects on vascular control varied as a result of different serum levels of indomethacin; there may be considerable variation in serum indomethacin concentration after the same dose in different babies (41).

Conclusions. Administration of indomethacin significantly reduced $\left[\mathrm{CytO}_{2}\right]$ in the majority of infants studied, whereas equipotent concentrations of indomethacin had no effect on oxygen metabolism in synaptosomes. This is consistent with the hypothesis that $\left[\mathrm{CytO}_{2}\right]$ declined as a result of alterations in intracellular oxygen availability due to hemodynamic perturbations. However, metabolic and hemodynamic heterogeneity prevent the finding of a simple relation between $\mathrm{COD}$ and $\left[\mathrm{CytO}_{2}\right]$.

Acknowledgments. The authors thank Clare Elwell, Dr. S. C. Roth, P. van der Zee, Clare Thorn, and the staff of the Neonatal Unit and the Department of Medical Physics and Bioengineering for their help.

\section{REFERENCES}

1. Edwards AD, Wyatt JS, Richardson C, Potter A, Cope M, Delpy DT, Reynolds EOR 1990 Effects of indomethacin on cerebral haemodynamics in very preterm infants. Lancet 335:1491-1495

2. Pryds O, Greisen G, Johansen KH 1988 Indomethacin and cerebral blood flow in preterm infants treated for patent ductus arteriosus. Eur J Pediatr 147:315 316

3. Altman DI, Perlman JM, Volpe JJ, Powers WJ 1989 Cerebral oxygen metabolism in newborn infants measured by positron emission tomography. $J$ Cereb Blood Flow Metab 9:S25(abstr)

4. Ment LR, Duncan CC, Ehrenkranz RA, Kleinman CS, Pitt BR, Taylor KJW Scott DT, Stewart WB, Gettner P 1985 Randomized indomethacin trial for prevention of intraventricular hemorrhage in very low birth weight babies. J Pediatr 107:937-943

5. Bada HS, Green RS, Pourcyrous M, Leffler CW, Koranes SB, Magill HL Arheart K, Fitch C, Garland DA, Somel G, Tullis K, Campbell J 1989 Indomethacin reduces the risks of severe intraventricular hemorrhage. J
Pediatr 115:631-637

6. Cope M 1991 The development of a near infrared spectroscopy system and its application for non-invasive monitoring of cerebral blood and tissue oxygenation in the newborn infant. PhD thesis, University of London, London, England

7. Jobsis FF, Keiner JH, LaManna JC, Rosenthal M 1977 Reflectance spectrophotometry of cytochrome $\mathrm{aa}_{3}$ in vivo. J Appl Physiol 43:858-872

8. Delpy DT, Cope M, van der Zee P, Arridge SR, Wray SC Wyatt JS 1988 Estimation of optical pathlength through tissue from direct time of flight measurement. Phys Med Biol 33:1433-1442

9. Cope M, Delpy DT 1988 A system for long-term measurement of cerebral blood and tissue oxygenation in newborn infants by near-infrared transillumination. Med Biol Eng Comp 26:289-294

10. Wray S, Cope M, Delpy DT, Wyatt JS, Reynolds EOR 1988 Characterisation of the near infrared absorption spectra of cytochrome $a_{3}$ and hemoglobin for the noninvasive monitoring of cerebral oxygenation. Biochim Biophys Acta 933:184-192

11. Wyatt JS, Cope M, Delpy DT, van der Zee P, Arridge S, Edwards AD, Reynolds EOR 1990 Measurement of optical pathlength for near-infrared spectroscopy in newborn infants. Dev Neurosci 12:140-144

12. Cope M, van der Zee P, Essenpries M, Arridge SR, Delpy DT 1991 Data analysis methods for near infrared spectroscopy of tissue: problems in determining the relative cytochrome $a_{3} a_{3}$ concentration. Proc SPIE 1431:251262

13. Edwards AD, Wyatt JS, Richardson C, Delpy DT, Cope M, Reynolds EOR 1988 Cotside measurement of cerebral blood flow in ill preterm infants by near infrared spectroscopy. Lancet 2:770-771

14. Wyatt JS, Cope M, Delpy DT, Richardson CE, Edwards AD, Wray S, Reynolds EOR 1990 Quantitation of cerebral blood volume in human infants by nearinfrared spectroscopy. J Appl Physiol 68:1086-1091

15. Wyatt JS, Edwards AD, Cope M, Delpy DT, McCormick DC, Potter A, Reynolds EOR 1991 Response of cerebral blood volume to changes in arterial carbon dioxide tension in preterm and term infants. Pediatr Res 29:553-557

16. Armitage P, Berry G 1987 Statistical Methods in Medical Research, 2nd Ed. Blackwell Scientific Publications, Oxford, England

17. Pearson ES, Hartley HO 1966 Biometrika Tables for Statisticians, Vol 1, 3rd Ed. Cambridge University Press, Cambridge, England

18. Dodd PR, Hardy JA, Oakley AE, Edwardson JA, Perry ER, Delauney JP 1981 A rapid method for preparing synaptosomes: comparison with alternative procedures. Brain Res 226:107-118

19. Edwards AD, Brown GC, Cope M, Wyatt JS, McCormick DC, Roth SC, Delpy DT, Reynolds EOR 1991 Quantification of changes in the concentration of cerebral oxidized cytochrome oxidase. J Appl Physiol 71:1907-1913

20. Zijlstra WG, Buursma A, Meeuwsen-van der Roest WP 1991 Absorption spectra of human fetal and adult oxyhemoglobin, deoxyhemoglobin, carboxyhemoglobin and methemoglobin. Clin Chem 37:1633-1638

21. Piantadosi CA, Jobsis-Vandervliet FF 1984 Spectrophotometry of cerebral cytochrome $\mathrm{a}_{\mathrm{a}} \mathrm{a}_{3}$ in bloodless rats. Brain Res 305:89-94

22. Ferrari M, Hanley DR, Wilson DA, Traystman RJ 1990 Redox changes in cat brain cytochrome c oxidase after blood-fluorocarbon exchange. Am J Physiol 258:H1706-H1713

23. Beinert H, Shaw RW, Hanson RS, Hartzell CR 1980 Studies on the origin of the near infrared $(800-900 \mathrm{~nm})$ absorption of cytochrome oxidase. Biochim Biophys Acta 591:458-470

24. Araki R, Nashimoto I 1989 Multicomponent analysis of near infrared spectra of anaesthetized rat head. Il. Quantitative multivariate analysis of hemoglobin and cytochrome oxidase by non-negative least squares method. Adv Exp Med Biol 248:11-20

25. Pickard JD 1989 Role of prostaglandins and arachidonic acid derivatives in the coupling of cerebral blood flow to metabolism. J Cereb Blood Flow Metab 1:361-384

26. Leffler CW, Busija DW, Beasley DG, Fletcher AM 1986 Maintenance of cerebral circulation during hemorrhagic hypotension in newborn pigs: role of prostanoids. Circ Res 59:562-567

27. Mirro R, Leffler CW, Armstead W, Beasley DG, Busija DW 1988 Indomethacin restricts cerebral blood flow during pressure ventilation of newborn pigs. Pediatr Res 24:59-62

28. Pourcyrous M, Leffler C, Busija D 1990 Role of prostanoids in cerebrovascular responses to asphyxia and reventilation in newborn pigs. Am J Physiol 259:H662-H667

29. Malmstrom BG 1990 Cytochrome oxidase: some unsolved problems and controversial issues. Arch Biochem Biophys 280:233-241

30. Capaldi RA 1990 Structure and function of cytochrome $c$ oxidase. Annu Rev Biochem 59:569-596

31. Siesjo BK 1978 Cerebral Energy Metabolism. John Wiley and Sons, Chichester, England

32. Rich PR, West IC, Mitchell P 1988 The location of $\mathrm{Cu}_{\mathrm{A}}$ in mammalian cytochrome oxidase. FEBS Lett 233:25-30

33. Morgan JE, Wikstrom M 1991 Steady-state behavior of cytochrome c, cytochrome a and $\mathrm{Cu}_{\mathrm{A}}$ of cytochrome c oxidase in intact rat liver mitochondria. Biochemistry 30:948-958

34. Nair P, Whalen WJ, Buerk D $1975 \mathrm{PO}_{2}$ of cat cerebral cortex: response to breathing $\mathrm{N}_{2}$ and $100 \% \mathrm{O}_{2}$. Microvasc Res 9:158-165

35. Smith RH, Guilbear EJ, Reneau DD 1977 The oxygen tension field within discrete volume of cerebral cortex. Microvasc Res 13:233-240

36. Brown GC, Crompton M, Wray S 1991 Cytochrome oxidase content of rat 
brain during development. Biochim Biophys Acta 1057:273-275

37. Yaffe SJ, Friedman WF, Rogers D, Lang P, Ragni M, Saccar C 1980 The disposition of indomethacin in preterm babies. J Pediatr 97:1001-1006

38. Widdowson EM, Dickerson JWT 1961 Chemical composition of the body. In: Comar CL, Bronner F (eds) Mineral Metabolism. Academic Press, New York

39. Wilson DF, Rumsey WL, Green TJ, Vanderkooi JM 1988 The oxygen dependence of mitochondrial oxidative phosphorylation measured by a new optical method for measuring oxygen concentration. J Biol Chem 263:27122718

40. Borowsky IW Collins RC 1989 Metabolic anatomy of brain: a comparison of regional capillary density, glucose metabolism, and enzyme activities. J Comp Neurol 188:401-413

41. Brash AR, Hickey DE, Graham TP, Stahlman MT, Oates JA, Cotton RB 1981 Relation of plasma indomethacin levels to response of the ductus arteriosus. N Engl J Med 305:67-72 